\title{
IMPLEMENTASI KEBIJAKAN JAMINAN PRODUK PANGAN HALAL DI KOTA PALANGKA RAYA PROVINSI KALIMANTAN TENGAH
}

\author{
I Implementation of Halal Food Product Guarantee Policy in Palangka Raya City, \\ Central Kalimantan Province
}

\section{Hamberi* $^{*}$ \\ Bayu Dwi Saputra}

Universitas Muhammadiyah

Palangkaraya, Palangka Raya,

Central Kalimantan, Indonesia

email:

hamberi@umpalangkaraya.ac.id

\begin{abstract}
Abstrak
Penelitian ini bertujuan untuk mengetahui bagaimana Implementasi Undang-undang No.33 tahun 2014 tentang Jaminan Produk Halal di Kota Palangka Raya provinsi Kalimantan Tengah. Tipe penelitian yang digunakan adalah metode penelitian kualitatif dengan teknik analisis destriptif. Informan yang diambil dalam penelitian ini dialkukan dengan teknik purposive sampling dan snowball sampling.

Berdasarkan hasil penelitian mengenai implementasi Undang-undang no. 33 tahun 2014 tentang jaminan produk halal di kota Palangka Raya provinsi Kalimantan Tengah dapat disimpulkan bahwa implementasi sudah dilaksanakan namun belum berjalan secara optimal dan belum memberikan perubahan berarti pada masyarakat. Adapun saran yang bisa peneliti berikan pada pihak penyelenggara kebijakan jaminan produk halal di kota Palangka Raya hendaknya lebih menjalin kerjasama dengan instansi dan masyarakat agar kebijakan sertifikasi produk halal dapat berjalan dengan semestinya.
\end{abstract}

Kata Kunci:

Implementasi

Jaminan

Produk Halal

Setifikat Produk

\section{Keywords:}

Implementation

Guarantee

Halal Products

Product Certificate

\section{Accepted}

January 2016

\begin{abstract}
This study aims to determine how the Implementation of Law number 33 of 2014 concerning Halal Product Assurance in the City of Palangka Raya, Central Kalimantan province. The type of research used is qualitative research methods with descriptive analysis techniques. The informants taken in this study were conducted using purposive sampling and snowball sampling techniques.

Based on the results of research on the implementation of Law no. 33 of 2014 concerning guarantee of halal products in the city of Palangka Raya, Central Kalimantan province, it can be concluded that the implementation has been carried out but has not run optimally and has not provided meaningful changes to the community. The advice that researchers can give to the organizers of the guarantee policy for halal products in the city of Palangka Raya should be to collaborate more with agencies and communities so that the halal product certification policy can run properly.
\end{abstract}

\section{Published}

April 2016

\section{PENDAHULUAN}

Indonesia sebagai negeri dengan penduduk muslim terbesar yaitu sebanyak 193.600.000 jiwa dari total jumlah penduduk 220 juta jiwa, sangatlah wajar jika panganan halal menjadi isu yang cukup menarik untuk dikaji dan diperbincangakan (BPS,2007). Hal ini dikarenakan semakin pesatnya perkembangan teknologi pangan terutama agroindustri pangan olahan yang mengakibatkan penggunaan bahan (ingredient) dalam pengolahan pangan menjadi sangat bervariasi. Masalah yang kemudian timbul adalah banyaknya bahan pangan, baik bahan baku utama maupun bahan aditifnya, yang sulit ditentukan kehalalalan asal bahan pembuatnya.

Sertifikasi produk halal telah tercantum dalam Undang-undang nomor 33 tahun 2014 tentang Jaminan Produk halal, yang mewajibkan setiap produk olahan makanan wajib memiliki label halal dalam produk. Aturan tentang label halal dan iklan pangan diperinci pada Peraturan Pemerintah 
Nomor 69 Tahun 1999 tentang label dan iklan pangan. Pada pasal 3 ayat 2. Persyaratan minimal keterangan yang harus tercantum dalam label tidak lagi mencantumkan keterangan halal sebagai salah satu persyaratan sebagaimana pada UU pasal 30 ayat 2. Di dalam peraturan pemerintah ini aturan tentang label halal tercantum dalam pasal 10 dan pasal II.

Pasal 10 ayat I menyatakan, bahwa setiap orang yang memproduksi dan memasukan pangan yang dikemas ke dalam wilayah Indonesia untuk diperdagangkan dan menyatakan bahwa pangan tersebut halal bagi umat islam, bertanggung jawab atas kebenaran pernyataan tersebut dan wajib mencantumkan keterangan atau tulisan halal pada label.

Sedangkan pasal II ayat I menyatakan, bahwa untuk mendukung kebenaran pernyataan halal sebagaimana yang dimaksud dalam Pasal 10 ayat I, setiap orang yang memproduksi atau memasukan pangan yang dikemas ke dalam wilayah Indonesia untuk diperdagangkan, wajib memeriksakan terlebih dahulu pangan tersebut pada lembaga pemeriksa yang telah diakreditasi sesuai dengan ketentuan peraturan perundang-undangan yang berlaku.

Sebagain provinsi dan daerah sudah memiliki peraturan daerah yang mengatur tentang sertifikasi produk halal sendiri, Provinsi dan daerah yang sudah memiliki peraturan daerahnya sendiri, diantaranya: Kalimantan Barat, Kalimantant Timur, jawa Barat, Bandung, Bangka Belitung dan Aceh.

$\mathrm{Di}$ indonesia saat ini meningkatnya produk luar negeri dan maraknya bahan makanan impor yang sudah masuk pasar nasional tetapi masih diragukan kehalalannya. Jadi, pelaku usaha seperti UMKM diwajibkan memiliki sertifikasi produk halal, hal ini merupakan upaya pemerintah dalam melindung konsumen dan pelaku usaha agar apa yang di olah dan dikonsumsi itu layak untuk masyarakat serta diharapkan juga dapat meningkatkan daya saing dengan produk luar daerah hingga luar negeri.

Prosedur dalam pembuatan sertifikasi label halal dilakukan oleh dua lembaga pemerintahan, yaitu LPPOM dan Majelis Ulama Indonesia (MUI). Prosedur yang dilakukan dalam pembuatan sertifikasi halal tersebut dilakukan setiap masyarakat yang ingin produknya diberi sertifikat halal. Setiap produk halal yang akan diberi label halal produk, harus terdaftar PIRT, kemudian tim audit LPPOM dan MUI akan meninjau dan mengevaluasi produk tersebut.

Sebagai kota yang memiliki penduduk muslim terbanyak di Kalimantan Tengah, maka isu kehalalan produk sangat berpengaruh di kota Palangka Raya. Sertifikasi produk halal pun menjadi sangat penting untuk para pelaku usaha makanan siap saji dan kemasan, karena di Kota Palangka Raya saat ini sedang marak iru makanan siap saji yang mengandun bahan tidaklayak konsumsi dan bahan haram bagi umat muslim. Maka sertifikasi produk halal dapat dijadikan pelindung bagu pelaku usaha dan konsumen.

\section{Kebijakan Publik}

Menurut Frederich (Agustino,2014:7) kebijakan adalah serangkaian kegiatan yang diusulkan oleh kelompok atau pemerintah dalam suatu lingkungan yang terdapat hambatan-hambatan atau kesempatan dan kebijakan dimaksudkan untuk mengatasi tujuan tersebut. Sedangkan menurut Eulaw dan Frewit (Tangkilisan,2007:5), kebijakan adalah keputuran tetap yang dicirikan oleh konsistensi dan pengulangan tingkah laku dari mereka yang membuat dari mereka yang mematuhi peraturan tersebut.

Kebijakan publik secara sederhana merupakan konsep dasar rencana pemerintah atau organisasi publik untuk mengatur kepentingan umum atau orang banyak. Sedangkan secara umum, kebijakan publik adalah segala sesuatu yang dikerjakan dan 
tidak dikerjakan oleh pemerintah untuk kepentingan umum. Segala sesuatu yang dimaksud adalah setaip aturan dalam kehidupan bersama, baik itu hubungan antar warga maupun warga dengan pemerintah.

Kebijakan publik biasanya dituangkan dalam peraturan perundang-undangan seperti undangundang (UU), peraturan presidenm dan peraturan daerah (Perda). Menurut Young dan Quinn (Suharto ,2014:44) kebijakan publik adalah tindakan yang dibuat dan diimplementasikan oleh badan pemerintah yang memiliki kewenangan hukum, politik, dan finansial untuk melakukannya.

Adapun jenis-jenis kebijakan publik, menurut Pasolong (20/3:40), menyatakan bahwa jenis-jenis kebijakan publik dapat ditelusuri melalui Undangundang Nomor 10 Tahun 2004 tentang Pembentukan Peraturan Perundang-undangan, pasal 7 menjelaskan jenis dan hirarki Peraturan Perundang-undangan sebagai berikut: (I) Undangundang Dasar Negara Republik Indonesia, (2) Undang-undang/Peraturan Pemerintah Pengganti Undang-undang, (3) Peraturan Pemerintah, (4)Peraturan Daerah.

\section{Implementasi Kebijakan}

Implementasi kebijakan secara sederhana dirumuskan oleh Wahab (Anggara, 2015:530) implementasi sebagai suatu proses melaksanakan keputusan kebijakan, yang biasanya dalam bentuk undang-undang, peraturan pemerintah, keputusan peradalian, perintah eksekutif, atau dekrit presiden. Dikatakan oleh George C. Edward (Subarsono,2015:89), implementasi kebijakan dipengaruhi oleh 4 variabel, yaitu komunikasi, sumber daya, disposisi, dan struktur birokrasi. Ke empat aspek tersebut mempengaruhi keberhasilan suatu pelaksaan program kebijakan dalam mencapai tujuan.

Ada beberapa model implementasi kebijakan publik yang dikemukakan oleh para ahli. Menurut Wibawa
(Tangkilisan,2007:138), implementasi kebijakan merupakan pengejawantahan keputusan mengenai kebijakan yang mendasar, biasanya tertuang dalam satu undang-undang, namun juga dapat berbentuk instruksi-instruksi eksekutif yang penting atau keputusan perundangan. Menurut Agustino (Agustino, 2014:139), implementasi merupakan suatu proses yang dinamis, dimana pelaksana kebijakan melakukan suatu aktivitas atau kegiatan sehingga akhirnya akan mendapatkan suatu hasil yang sesuai dengan tujuan atau sasaran kebijakan itu sendiri. Ripley dan Franklin (Tahir,20|4:95) mengemukakan bahwa kriteria pengukuran keberhasilan implementasi kebijakan didasarkan pada tiga aspek, yaitu: (I)Tingkat kepatuhan birokrasi terhadap birokrasi diatasnya atau tingkatan birokrasi sebagaimana ditaur dalam undang-undang, (2)Adanya kelancaran rutinitas dan tidak adanya masalah, serta (3)Pelaksanaan dan dampak (manfaat) yang dikehendaki dari semua program yang ada terarah.

\section{Produk Pangan Halal}

Kata Halalan berasal dari bahasa Arab "Halala" yang berarti "lepas" atau "tidak terikat". Secara etimologi, kata halalan berarti hal-hal yang bolhe dan dapat dilakukan karena bebas atau tidak terikat dengan ketentuan-ketentuan yang melarangnya. Dapat juga diartikan sebagai segala sesuatu yang bebas dari bahaya duniawi dan ukhrawi. Maknaan dan minuman halal adalah (I)Bukan terdiri dari atau mengandung bagian /benda dari hewan yang dilarang oleh syariat islam untuk memakannya, atau hewan yang tidak disembelih menurut syariat Islam, (2) tidak mengandung sesuatu yang dihukumi najis menurut syariat Islam, (3) tidak mengandung bahan penolong atau bahan tambahan yang diharamkakan dalam syariat Islam, (4) dalam proses, menyimpan, dan menghidangkan tidak bersentuhan atau berdekatan dengan makanan yang tidak memenuhi 
persyaratan sebagaimana di atas atau benda yang dihukumkan sebagai nahis menurut syariat islam.

\section{Jaminan Label Produk Halal}

Label adalah bagian dari sebuah produk yang berupa keterangan/penjelasan mengenai barang tersebut atau penjualnya (Gitosudarmo, 2000). Sedangkan yang dimaksud produk halal menurut LPPOM adalah produk yang memenuhi syarat kehalalan sesuai syari'at Islam. Labelisasi halal adalah pencantuman tulisan atau pernyataan halala pada kemasan produk untuk menunjukan bahwa produk yang dimaksud berstatus sebagai produk halal. Label halal sebuah produk dapat dicantumkan pada sebuah kemasan apabila produk tersebut telah mendapatkan sertifkat halal oleh LPPOM MUI. Sertifikasi dan labelisasi halal bertujuan untuk memberikan kepastian hukum dan perlindungan terhadap konsumen, serta meningkatkan daya saing produk dalam negeri.

Indikator labelisasi produk halal ada tiga, yaitu:

a. Pengetahuan, merupakan informasi atau maklumat yang diketahui atau disadari oleh seseorang. Pengetahuan adalah informasi yang telah dikombinasikan denga pemahaman dan potensi yang lantas melekat di benak seseorang.

b. Kepercayaan, merupakan suatu keadaan psikologis pada saat seseorang menganggap suatu premis benar.

c. Penilaian terhadap labelisasi halal, merupakan proses, cara, perbuatan menilai/pemberian nilai terhadap label hala suatu produk.

Syarat kehalalan suatu produk meliputi:

I. Tidak mengandung DNA babi dan bahan-bahan tradisional yang berasal dari babi

2. Tidak mengandung bahan-bahan yang diharamkan seperti : bahan yang berasal dari organ tubuh manusia, darah, dan kotorankotoran
3. Semua bahan yang berasal dari hewan yang dilarang dalam syariat Islam

4. Semua tempat penyimpanan, tempat pengolahan, tempat penjualan, dan transportasinya tidak boleh digunakan untuk bahan haram. Jika pernah digunakan untuk bahan haram, maka terlebih dahulu dibersihkan dengan tata cara yang diatur syariat.

Setiap produsen yang mengajukan sertifikasi halal bagi produknya harus melampirkan spesifikasi dan sertifikat halal bahan baku, bahan tambahan, dan bahan penolong serta bahan aliran proses. Surat keterangan tersebut bisa dari MUI daerah (produk lokal) atau lembaga Islam yang diakui oleh MUI (produk impor) untuk bahan yang berasal dari hewan dan turunannya.

Setelah itu tim auditor LPPOM MUI melakukan pemeriksaan dan audit ke lokasi produsen yang bersangkutan serta penelitian dalam laboratorium yang hasilnya dievaluasi oleh rapat tenaga ahli LPPOM MUI yang terdiri dari ahli gizi. Biokimia, pangan, teknologi pangan, teknik pemprosesas, dan bidang lain yang terkait. Bila memenuhi persyaratan, laporan akan diajukan kepada sidang Komisi Fatwa MUI untuk memutuskan kehalalalan produk tersebut.

Tidak semua laporan yang diberikan LPPOM MUI langsung disepakati Komisi Fatwa MUI. Terkadang, terjadi penolakan karena dianggap belum memenuhi persyaratan. Dalam kerjanya bisa dianalogikan bahwa LPPOM MUI adalah jaksa yang membawa kasus ke pengadilan dan MUI adalah yang memutuskan keputusan hukumnya.

Sertifikat halal berlaku selama dua tahun. Sedangkan untuk daging yang diekspor, sertifikat diberikan pada setiap pengepalan. Dalam rentang waktu tersebut, produsen harus bisa menjamin kehalalalan produknya. Proses penjaminannya dengan pengangkatan Auditor Halal Internal untuk 
memeriksa dan mengevaluasi Sistem jaminan Halal (Halal Assurance System) di dalam perusahaan.

Auditor Halal tersebut di syaratkan harus beragama Islam dan berasal dari bagian terkait dengan produksi halal. Hasil audit oleh auditor ini dilaporkan kepada LPPOM MUI secara periodik (enam bulan sekali) dan bila diperlukan LPPOM MUI melakukan inspeksi mendadak dengan membawa surat tugas.

\section{METODOLOGI}

Metode penelitian yang digunakan adalah Metode Kualitatif dengan merujuk kepada pendapat yag diungkapkan oleh Moleong (2004:8) (I) Tindakan pengamatan mempengaruhi apa yang dilihat, karena itu hubungan penelitian harus mengambil tempat pada keutuhan dalam konteks untuk keperluan pemahaman, (2) konteks sangat menentukan daalam menetapkan apakah suatu penemuan mempunyai arti bagi konteks lainnya, yang berarti bahwa suatu fenomena harus ditliti dalam keseluruhan pengaruh lapangan, (3) sebagai struktur nilai kontekstual bersifat determinative terhadap apa yang akan dicari, serta data yang diperoleh dalam bentuk informasi baik lisan maupun tulisan.

Sumber data primer diperoleh melalui observasi dan wawancara kepada pengelola dan pejabat struktural di kantor Majelis Ulama Indonesia di kota Palangka Raya. Data sekunder diperoleh dari Kantor Majelis Ulama Indonesia di Kota Palangka Raya dan Badan Pemeriksa Olahan Makanan Kota.

\section{HASIL DAN PEMBAHASAN}

Berdasarkan penelitian yang telah dilaksanakan, peneliti menemukan beberapa hal yang harus diperhatikan dari implementasi kebijakan sertifikasi produk halal di kota Palangka Raya. Disimpulkan bahwa pencapaian implementasi tersebut belum optimal karena adanya faktor-faktor yang bisa menjadi penghambat. Meskipun Lembaga Pengkajian Pangan Obat-obatan dan Makanan Majelis Ulama Indonesia (LPPOM MUI) yang bertanggung hawab penuh atas pembuatan sertifikasi produk halal ini sudah melakukan berbagai cara untuk meningkatkan kesadaran serta partisipasi masyarakat dalam pengurusan sertifikasi produk halal.

Mengingat undang-undang nomor 33 tahun 2014 tentang sertifikasi produk halal yang mengatakan bahwa seluruh produk harus memiliki sertifikasi produk halal masih bersifat sukarela. Walaupun masih bersifat suakrela, perlindungan konsumen perlu diperhatiakn karena apa yang kita konsumsi belum tentu aman untuk tidak hanya aman untuk umat muslim namun juga untuk masyarakat non muslim.

Berbagai daerah dan provinsi sudah memiliki peraturannya sendiri untuk melindungi konsumen dan produsen di daerah mereka. Di kota Palangka Raya sendiri masih memerlukan banyak persiapan agar masyarakat mau membuat sertifikasi produk halal,.

I. Perspektif Kepatuhan Birokrasi yang Lebih Rendah Terhadap Birokrasi di atasnya

Tingkat kepatuhan birokrasi dalam Implementasi kebijakan sertifikasi produk halal di kota Palangka Raya sudah terkoordinasi oleh Majelis Ulama Indonesia Provinsi Kalimantan Tengah. Tugas dan wewenangnya di setiap instansi sudah memiliki perannya masingmasing, seperti dinas kesehatan berwenang dengan pengurusan izin produk rumah tangga (PIRT) serta sebagai pemberi label dalam kemasan, badan pemeriksa olahan obat dan makanan berperan untuk menguji kelayakan dan kualitas makanan tersebut, dan lembaga pengkajian pangan dan obat-obatan dan 
kosmetika Majelis Ulama Indonesia (LPPOM MUI) yang berperan dalam pengurusan sertifikasi produk halal.

Lembaga dan instansi sudah patuh atas tugas yang dipercayakan Majels Ulama Indonesia untuk bekerja sama dalam pembuatan sertifikasi produk halal. Dilihat dari kerjasama serta kepatuhannya terhadap birokrasi antar lembaga, tidak ada yang diatas maupun di bawah dalam pengurusan label halal seluruh instansi bekerja sama dalam peningkatan kesadaran masyarakat akan pentingnya sertifikasi produk halal.

Menurut Ripley dan Franklin dalam Arifin Tahir (2014:95) tingkat kepatuhan birokrasi yaitu setiap aparatur dalam birokrasi atau implementator kebijakan publik dituntut memiliki sikap yang mewujud pada tindakan yang patuh dan taat asas dalam melaksanakan setiap kebijakan, hal ini masih belum sejalan dengan teori yang dikemukakan oleh Ripley dan Franklin melihat dari kepatuhan birokrasinya memang sudah berjalan dengan baik namun dalam ruang lingkup administrasi kota palangka raya kebijakan jaminan produk halal dikatakan belum berhasil karena masih perlu sering diadakannya sosialisasi dan bantuan dari pemerintah serta instansi terkati agar masyarakat mau patuh dengan pemerintah, karena dalam pembuatan sertifikasi produk halal buth dana yang cukup besar bagi pelaku usaha mikro kecil dan menengah.

2. Persepsi Kelancaran Rutinitas dan Tiadanya Masalah

Kelancaran rutinitas seperti prosedur dalam pembuatannya menurut narasumber yang ditemui oleh peneliti, prosedur pembuatannya tidak rumit. Memang dalam pengurusannya dapat memakan waktu yang lama serta menelan biaya yang cukup besar, namun itu semua sudah menjadi standar bagi para implementor karena dalam prosedur pembuatannya memang membutuhkan waktu yang cukup lama karena perlu melalui beberapa tahapan-tahapan. setiap produk harus sudah memiliki izin industri dari Dinas Kesehatan, dan sudah di uji coba oleh Badan Pemeriksa Olahan Makanan, kemudian bila sudah melengkapi persyaratannya baru didaftarkan ke LPPOM MUI untuk menjalani auditnya.

Namun yang menjadi masalah dalam pengurusannya adalah ketidak pahaman masyarakat dalam pengurusannya, ditambah lagi ketika masyarakat mengetahui berapa biaya yang harus dikeluarkan, membuat pelaku usaha berfikir kembali untuk mengurusnya. Hal ini disebabkan karena sosialisasi yang disampaikan kepada wirausahawan masih belum menyeluruh. Keterbatasan anggaran dalam penyampaian sosialisasi kepada wirausaha masih belum ada dari pemerintah. Kemudian kendala yang ditemui peneliti dalam kelancaran ruitinitasnya yaitu kurangnya pegawai administratif yang ada di LPPOM MUI untuk menangani pendaftaran untuk sertifikasinya. Dengan kata lain kelancaran rutinitas untuk sertifikasi produk halal masih belum maksimal karena masih banyak kendala-kendala yang dihadapi.

Menurut Ripley dan Franklin dalam Arifin Tahir (2014:96), kelancaran rutinitas dan tiada masalah dalam hal ini implementor kebijakan publik sedapat mungkin meminimalisir setiap permasalahan yang ditemui dalam proses implementasi kebijakan publik. Setiap implementor menjadi Problem Solver dan bukan menjai pemicu masalah. Dalam hal ini kondisi lapangan masih belum sesuai dengan apa yang disampaikan oleh Ripley dan Franklin, Karena dalam hal ini pemerintah masih kurang aktif untuk mengatasi kebijakan mengenai jaminan produk halal karena tidak ada landasan hukum 
dan peraturan yang kuat untuk pelaksanaan sertifikasi produk halal. Dalam hal ini implementor tidak menjadi pemicu masalahnya. Yang menjadi pemicunya adalah tingkaan atas yang lebih mengurus kebijakan dalam hal membuat peraturan dan landasan hukum yang tegas.

3. Perspektif Pelaksanaan yang Mengarah Kepada Kinerja yang Memuaskan Semua Pihak Terutama Penerima Manfaat yang Diharapkan Perpektif pelaksanaan yang mengarah kepada kinerja yang memuaskan semua pihak terutama penerima manfaat yang diharapkan. Menurut Ripley dan Franklin dalam Arifin Tahir (2014:96) yaitu setiap pelaksanaan kebijakan pada akhirnya bermuara pada efektif tidaknya proses implementasi dari kebijakan itu sendiri. Efektifitas proses implementasi kebijakan tentunya akan melahirkan apa yang disebut optimalisasi kinerja kebijakan pun ditentukan kinerja individu dan para implementor kebijakan itu sendiri.

Dalam hal ini di lapangan tidak sejalan dengan apa yang dikatakan oleh Ripley dan Franklin, dapat dilihat dari kinerja serta koordinasi antar instansi dan masyarakat dalam pelaksanaan sertifikasi produk halal. $\mathrm{Hal}$ yang ditemui peneliti, kinerja lembaga Majelis Ulama Indonesia di Palangka Raya provinsi Kalimantan Tengah masih belum optimal karena dalam pelaksanaannya fasilitas serta jumlah pegawai yang tidak mencukupi untuk kelancaran berjalannya kebijakan tersebut. Namun beserta instansi pemerintahan seperti Dinas Kesehatan kota Palangka Raya sudah cukup baik. Kedua instansi tersebut sudah sering melaksanakan pertemuan untuk membahas sertifikasi produk halal dalam koordinasinya. Disamping itu instansi yang bekerja sama selalu mengarahkan masyarakat untuk membuat sertifikasi.

\section{KESIMPULAN}

Bahwa Implementasi kebijakan sertifikasi produk halal sudah berjalan, namun masih belum optimal karena kebijakan sertifikasi produk halal dasarnya masih belum kuat mengingat undang-undang no 33 tahun 2014 tentang sertifikasi produk halal masih bersifat polateri atau bersifat sukarela. Seharusnya pemerintah kota Palangka Raya beserta provinsi Kalimantan Tengah harus suah memiliki peraturan daerahnya sendiri mengingat pasar perindustrian kian meningkat karena bersamaan dengan peningkatan produk-produk dari luar yang sudah mula masuk pasar nasional. Perlindungan konsumen perlu ditingkatkan mengingat indonesia mayoritas penduduknya pemeluk agama islam. Tidak hanya penduduk muslim yang harus dilindungi namun juga masyarakat Non Muslim.

Faktor-faktor yang menjadi penghambat atau kendala yang dihadapi dalam pelaksanaan kebijakan sertifikasi produk halal oleh lembaga Pengkajian Pangan Obat Obatan dan Kosmetika Majelis Ulama Indonesia (LPPOM MUI), Badan Pemeriksa Olahan Makanan (BPOM), dan Dinas Kesehatan kota Palangka Raya yaitu sosialisasi, peningkatan partisipasi masyarakat dan peraturna pemerintah kota dan provinsi Kalimantan Tengah yang masih belum kuat untuk mengatur kebijakan jaminan produk halal. Jaminan produk halal adalah suatu jaminan bahwa setiap produk yang sudah memiliki sertifikasi aman untuk dikonsumsi oleh konsumen, terutama konsumen muslim. Peran pemerintah kota Palangka Raya sebaiknya sudah memiliki dasar hukum yang kuat untuk kebijakan ini. Mengingat bahwa provinsi dan daerah lain sudah memiliki dasar yang kuat untuk perlindungan masyarakat yang berusaha melindungi konsumen. Karena tanggung jawab pemerintah adalah melayani dan melindungi rakyatnya. 


\section{REFERENSI}

Anggara, Sahya. 2015. Ilmu Administrasi Negara. Bandung: Pustaka Setia.

Agustino,Leo. 2014. Dasar-dasar Kebijakan Publik. Bandung: Alfabeta.

Bahruddin. 2010. Probelm Sertifikasi Halal Produk Pangan Hewani. Jurnal ilmu pendidikan, (online), Jilid 2, No. I, (Http://www.portalgaruda.ac.id. Diakses 20 April 2017)

Hamdi, Muchlis. 20I4. Kebijakan Publik. Bogor: Ghalia Indonesia

Huberman. 2012. Panduan menulis Skripsi. Fisip UMP, Palangka Raya.

Pasolong, Harbani. 2007. Teori Administrasi Public. Bandung: Alfabeta

Suharto, Edi. 20I4. Analisis Kebijakan Publik. Bandung: Alfabeta

Subarsono. 2015. Analisis Kebijakan Publik. Yogyakarta: Pustaka Pelajar
Tangkilisan. 2007. Kebijakan dan Manajemen Otonomi Daerah. Yogyakarta: Lukman Offset.

Tahir, Arifin. 2014. Kebijakan Publik dan Transparasi Penyelenggaraan Pemerintah Daerah. Bandung: Alfabeta.

Toun, N. R., \& Nufus, H. 20I5. Implementasi Program Pusat Informasi Konseling Mahasiswa (PIK-M) BKKBN di Kota Palangka Raya. Restorica: Jurnal Ilmiah IImu Administrasi Negara Dan Ilmu Komunikasi, I(I), I-4.

Wahab, Abdul Solichin. 20I5. Analisis Kebijakan. Jakarta: PT. Bumi Aksara.

Yusuf, M., \& Kobota, K. 2015. Implementasi Kebijakan Pengelolaan Inventaris Barang Bergerak Milik Daerah di Lingkungan Pemerintah Kota Palangka Raya. Pencerah Publik, 2(I), I-5. 